\title{
Supporting student teachers' reflective attitude and research-oriented stance
}

\author{
Christine Bieri Buschor $^{1}$ • Esther Kamm ${ }^{1}$
}

Published online: 16 September 2015

C Springer Science+Business Media Dordrecht 2015

\begin{abstract}
Following a major shift in Swiss teacher education in the 1990s, teachers are now educated at the university level with a more research-oriented focus than before the reform. Furthermore, the curriculum in teacher education is not only more academically oriented, but also concurrently practice-focused. Swiss student teachers are highly involved in the clinical practical component from the outset. This approach provides more learning opportunities that help to strengthen the relationship between theory and practice. Prior to the reform, reflection on teaching was mainly incorporated into practical training. However, since the reform, reflection has been strongly embedded in the entire curriculum in order to support student teachers' reflective competence. The aim of this article is to discuss how students can be supported in developing a reflective attitude and a research-oriented stance, which have traditionally been seen as core elements of professional development. Three learning settings are presented, ranging from a more traditional approach to conducting research, to a current video-based training programme. Finally, consequences for teacher education are discussed.
\end{abstract}

Keywords Research-oriented teacher education - Reflective attitude $\cdot$ Research-oriented stance Action research - Video-based training

\section{Introduction}

\subsection{Teacher education (torn) between research and practice}

Over the past decade, internationalization of the higher education system has had a strong impact on national education policies. As a consequence, teacher education, which has tradi-

\footnotetext{
Christine Bieri Buschor

christine.bieri@phzh.ch

Esther Kamm

esther.kamm@phzh.ch
}

1 Pädagogische Hochschule Zürich, Zurich University of Teacher Education,

Lagerstrasse 2, 8090 Zürich, Switzerland 
tionally been considered as part of further professional education in many European countries, was incorporated as part of the higher education system (Kyvik 2009; OECD 2005). Likewise, there has been a remarkable change in Swiss teacher education. Following a major shift in the 1990s, teachers are now educated at the university level, with a more researchoriented focus in the curriculum than before the reform. Furthermore, the curriculum is not only more academically oriented, but also concurrently focused on practice (Criblez 2008; Denzler 2014). Swiss student teachers are highly involved in clinical practice in schools from the outset. This approach provides more learning opportunities to strengthen the relationship between theory and practice, including reflection on students' experiences in the classroom. Prior to the reform, reflection on teaching was mainly incorporated into the teaching practice component (practicum). However since the reform, reflection has been strongly embedded in the entire curriculum in order to support student teachers' reflective attitudes. Teachers require a high level of reflective and inquiring competencies to counteract uncertainty in teaching (Helsing 2007; Ostermann and Kottcamp 2004). Therefore, a reflective practice and research-oriented stance have generally been seen as crucial components of developing teacher professionalism (Zeichner and Liston 1987; Zeichner 2010; Helsper and Kolbe 2002).

Despite worldwide calls for reflective and research-oriented teaching in order to empower teachers to develop their own professional knowledge, teacher education has traditionally been practice-centered (Ball and Forzani 2009; Darling-Hammond and Sclan 1996; Zeichner 2012). Therefore, calls for a more research-oriented approach remain controversial. In the case of Switzerland, the current teacher shortage has led to the lowering of admission requirements for the teacher education programmes and to the strengthening of practical training as opposed to research-based activities and reflective teaching. The latter has traditionally been described as the dominance of knowing how over knowing that (Riley 1949). Moreover, teacher education seems to attract a considerable amount of students who are not primarily interested in inquiring activities but are rather focused on practical work with children and adolescents (Denzler 2014; Denzler and Wolter 2009; Gitlin et al. 1999). As a consequence, teacher educators face several challenges in their endeavor to support student teachers not only to be thoughtful, reflective, and inquiring, but also to gain teaching skills in a practice-based learning environment. Therefore, the question arises of which learning settings in the higher education context of teacher education provide opportunities to strengthen future teachers' reflective attitudes and research-oriented stance.

The aim of this paper is firstly to discuss how student teachers can be supported in developing a reflective attitude toward teaching and a research-oriented stance. First, we outline the role of reflection in teaching. Second, we refer to the current discourse on research-oriented teacher education. Third, we present different schemes to analyze research-oriented learning activities in the curriculum. We then analyze three learning settings, namely (1) a more traditional approach related to action research, (2) a participatory research project in the field of special needs education, and (3) a new approach combining co-reflection and competence training based on a video study. Finally, we discuss the major implications and challenges for teacher education.

\subsection{Reflection and reflective teaching: building a bridge between theory and practice}

The concept of reflection, referring to a complex array of cognitive and philosophical approaches, has traditionally been seen as a core element of reflective teaching in terms of self-directed growth and teachers' professional development (Ottesen 2007; Schön 1983; Shulman 1987; Van Manen 1977, 1995; Zeichner and Liston 1987; Zeichner 2010). Since 
Dewey's work on teachers' reflective action $(1904,1933)$ in contrast to routine action, which is guided by tradition and external authority rather than by critical thinking, reflection has been understood as a set of processes through which professionals learn from experience (Shulman 1987; Van Manen 1995). In particular, the type of reflection in the very moment of action appears to be highly challenging. Referring to this temporal dimension, Schön (1983) introduced the concept of reflection-in-action, based on an underlying constructivist view of reality (Schön 1987). In this context, practitioners can learn by doing "We can not only think about doing but we can think about doing something while doing it" (Schön 1983, p. 54). Reflection-on-action, by contrast, is related to contemplating problems out of the flow of action. Reflecting upon one's actions is an important feature of professional development for two reasons: first, the practitioner's knowledge base is reorganized and broadened, and second, it can be made transparent in the communicative process (Altrichter and Posch 2007). Schön's concept has since been criticized due to its strong focus on the individual process and disregard of the environmental context. In recent works on teachers' reflection, mutual reflection (co-reflection) is strongly emphasized because it is assumed that shared reflection can help develop a critical perspective on one's own action. Therefore, teachers should be encouraged to focus not only on their own practice but also on collaborative practice (Zeichner and Liston 1996). Studies show that student teachers achieve higher levels of reflection when support structures are in place (Gelfuso and Dennis 2014). The measurement of different levels of reflection has gained importance due to new approaches to support student teachers' competence development (Wyss 2013). The descriptions of the levels of reflection are comparable to developmental stages, which range from lower levels, encompassing descriptions of personal thoughts, experiences, and aims, to higher levels, referring to theoretical concepts and content. The highest levels of reflection incorporate ethical, moral, and political considerations (Hatton and Smith 1995; Wyss 2013). However, developmental stages have often been criticized because they are not clearly definable.

Over the past decade, university-based teacher education has been challenged and there has been a push to support reflective teaching in practical situations in order to bridge the gap between theory and practice (Abell and Cennamo 2004; Gelfuso and Dennis 2014; Masats and Dooly 2011; Seidel et al. 2013; Zeichner 2010). Teacher educators have responded to this call by incorporating "approximations of practice" (Grossman and McDonald 2008) in terms of opportunities for reflective learning beyond the practicum into the curriculum, such as portfolios, blogs, and video- and competence-based training. Video-based exemplars of classroom practice have become popular because, when they are embedded in appropriate instructional contexts, they provide meaningful learning settings within which the acquisition and application of student teachers' knowledge can be guided (Admirall et al. 2011; Santagata and Guarino 2011; Seidel et al. 2013). Professional development through reflection using videos has gained attention particularly due to its positive effect on student teachers' competence development. Studies show that when comparing their own videos with those of others, teachers are more engaged in critical analysis (Kleinknecht and Schneider 2013). Moreover, a comparison with the classroom practice of others enhances the accuracy of self-evaluation and reflective teaching (Baecher et al. 2013; Hagevik et al. 2012).

\subsection{Research-oriented teacher education: from being reflective to conducting research}

Reflective teaching is strongly linked to research-oriented teaching. Reflective (student) teachers assess the origins, purposes, and consequences of their work on a regular basis. These inquiry components help them to understand classroom activities, schools, and cur- 
ricula within their respective contexts (Zeichner and Liston 1987). Shulman (1987) states that the teaching profession requires a knowledge base and principles of inquiry that help to answer questions relating to important ideas and skills in a specific subject. This knowledge base consists of content knowledge, pedagogical content knowledge, pedagogical reasoning, and action (Shulman and Shulman 2004). Students should become proficient in skills of inquiry in order to understand the culture of their classroom as well as subject-specific phenomena. Furthermore, they need to become creators of educational knowledge through action research, observations, ethnographic study, and curriculum analysis projects (Zeichner and Liston 1987; Shulman 1987; Shulman and Shulman 2004). As a consequence, Zeichner and Liston (1987) advocates an inquiry-oriented curriculum in teacher education.

The aim of research-oriented teacher education is to prepare teachers to control their own activities and to base their decision-making on research-derived arguments and critical thinking, in addition to experiential arguments. The goal is to (1) enhance student teachers' understanding of research (methods), (2) support their positive attitude towards research, and (3) equip them to undertake their own research (Kynäslahti et al. 2006). A positive attitude towards research can also be described as "inquiry as stance" (So 2013). "Stance" generally refers to the "lenses through which we see" (Cochran-Smith and Lytle 1999, p. 288). Inquiry as stance emphasizes the habit of mind or attitude for teaching practice in terms of "investigative habitus" (Cochran-Smith and Lytle 2009; Helsper and Kolbe 2002; So 2013).

Over the past few years, interest in collaborative inquiry as part of professional development has increased (Darling-Hammond 2010; Rigelman and Ruben 2012). The underlying rationale is that professional development facilitates the improvement of teaching practices (Antoniou and Kyriakides 2013; Borko et al. 2010; Cochran-Smith and Lytle 1993; Guskey 2000). The goal of collaborative inquiry is to move towards a system of problem-solving in communities of practice that promote the development of knowledge in the practitioners' context. The models of collaborative inquiry represent a wide range of options in terms of goals, processes, and types of data, analyses, and reflections. Some models, such as action research, range from more general school problems to more specific instructional issues and improvement of instruction (Clark and Fournillier 2012; Ermeling 2010; Hagevik et al. 2012; Schön 1987).

In sum, reflective teaching and collaborative inquiry are closely related. In accordance with professional development approaches, it is assumed that they facilitate improvement in teachers' practices. It has been argued that a reflective attitude and a research-oriented stance are core elements of professional development. In recent years, the call to support teachers' professional development has turned into a call for reflective teaching and research-oriented teacher education as a structural component of political and educational reforms (Ball 2008; Westbury et al. 2005). Concurrently, a worldwide movement to focus teacher education on core instructional practices can be observed (Ball and Forzani 2009; Denzler 2014; Kraler and Schratz 2012; Zeichner 2012). The discourse on research-oriented and practice-centered teacher education has also led to different didactical approaches and schemes to analyze research orientation.

\subsection{Schemes to analyze research orientation in teacher education}

The schemes to describe the requirements and goals of learning settings range from general analysis of the curriculum designs in higher education (Healey and Jenkins 2009; Healey 2005) to specific types of research in teacher education (Altrichter and Mayr 2004) and 


\begin{tabular}{ll|ll}
\multicolumn{4}{c}{ Students as participants } \\
$\begin{array}{lll}\text { Research-tutored } \\
\text { Emphasis on } \\
\text { content }\end{array}$ & $\begin{array}{l}\text { learriculum emphasizes } \\
\text { learning focused on } \\
\text { students writing and } \\
\text { discussing essays }\end{array}$ & $\begin{array}{l}\text { Research-based } \\
\text { curriculum emphasizes } \\
\text { students undertaking } \\
\text { inquiry-based learning }\end{array}$ & $\begin{array}{l}\text { Emphasis on } \\
\text { processes } \\
\text { and } \\
\text { problems }\end{array}$ \\
\cline { 2 - 4 } & $\begin{array}{l}\text { Research-led } \\
\text { curriculum is } \\
\text { structured and related } \\
\text { to the subject }\end{array}$ & $\begin{array}{l}\text { Research-oriented } \\
\text { curriculum emphasizes } \\
\text { teaching processes of } \\
\text { knowledge construction } \\
\text { in the subject }\end{array}$ & \\
& & &
\end{tabular}

Students as audience

Fig. 1 Scheme to analyze the nexus between research and teaching, including students' participation in the process adapted from Healey and Jenkins (2009)

competence models of teachers' reflection in action (Westbury et al. 2007). For our purposes, we will further describe the first two schemes.

Healey (2005) and Healey and Jenkins (2009) presented a scheme (or instrument) to analyze traditional and non-traditional learning settings in higher education. The authors refer to Griffiths' (2004) distinction between the following types of research-teaching nexus: (1) research-led, (2) research-oriented and (3) research-based learning. In the first type, students learn about research findings mainly by means of information transmission. In the second type, students learn about research processes. The curriculum emphasizes the process by which scientific knowledge is produced as well as learning knowledge that has been achieved. Lecturers try to engender a research ethos. The third type refers to students' learning in the role of researchers. The curriculum is primarily designed around inquiry-based activities, and students and teachers are seen as equals. Figure 1 illustrates Healey and Jenkins' (2005, 2009) scheme to analyze the correlation between learning settings and students' roles. The vertical axis reaches from student-focused activities with students in an active role to teacher-focused activities with students as the audience. The horizontal axis runs from a focus on research content to a focus on processes and problem-solving. It is important to note that each of the four types can be subdivided further, and that teaching, as well as research, are becoming more heterogeneous. Approaches to teaching and research are thus linked in different ways to research.

Altrichter and Mayr (2004) proposed a scheme to analyze different types of research in the field of teacher education. Table 1 contains six types of research with various aims and levels of requirement. These types have been extended by possible learning settings in higher education (Bieri Buschor et al. 2013).

The first two types are related to scientific literacy and students assume a recipient role rather than an active role as a researcher. The knowledge transmission occurs in the classroom. (1) Type 1 refers to acquisition of knowledge from research and studies that are relevant to teaching (e.g., results of large-scale assessments such as the TIMSS video study or case studies). The aim is to understand what these studies can (and cannot) provide and to choose criteria for reflection on teaching (e.g., criteria for high-quality mathematics teaching). (2) The second type aims to gain basic competences related to specific research methods in order to critically reflect on research in the field of teaching different subjects. Alternatively, stu- 
Table 1 Different types of research in teacher education

\begin{tabular}{|c|c|c|c|}
\hline & Type description & Aims & Learning settings \\
\hline 1 & $\begin{array}{l}\text { Acquisition of knowledge } \\
\text { (Re-constructing) }\end{array}$ & $\begin{array}{l}\text { - Acquisition of knowledge from } \\
\text { research and studies that are } \\
\text { relevant to teaching and } \\
\text { reflection (e.g., results of } \\
\text { large-scale assessments or case } \\
\text { studies) }\end{array}$ & $\begin{array}{l}\text { - Lectures } \\
\text { - Presentations } \\
\text { - Essays, assignments } \\
\text { - } \ldots\end{array}$ \\
\hline 2 & $\begin{array}{l}\text { Acquisition of basic } \\
\text { competences related to } \\
\text { research methods }\end{array}$ & $\begin{array}{l}\text { - Critical thinking } \\
\text { - Analysis related to criteria }\end{array}$ & $\begin{array}{l}\text { - Courses on research methods } \\
\text { - Workshops to analyze } \\
\text { cases/case studies }\end{array}$ \\
\hline & & $\begin{array}{l}\text { - Reflection based on results of } \\
\text { studies }\end{array}$ & $-\ldots$ \\
\hline 3 & $\begin{array}{l}\text { Participating in research } \\
\text { projects (continuation } \\
\text { of } 1 \text { and } 2 \text { ) }\end{array}$ & $\begin{array}{l}\text { - Conducting research in } \\
\text { research projects relevant to } \\
\text { teaching guided by experienced } \\
\text { researchers }\end{array}$ & $\begin{array}{l}\text { - Research and development } \\
\text { projects } \\
\text { - Evaluations } \\
\text { - Bachelor and Master thesis } \\
-\ldots\end{array}$ \\
\hline 4 & $\begin{array}{l}\text { Learning based on case } \\
\text { studies with a strong } \\
\text { focus on deep } \\
\text { comprehension }\end{array}$ & $\begin{array}{l}\text { - Gaining knowledge by means } \\
\text { of comparison (e.g., with expert } \\
\text { teachers, confrontation with a } \\
\text { case) in order to understand } \\
\text { patterns in a school or } \\
\text { interactions }\end{array}$ & $\begin{array}{l}\text { - Workshops focused on case } \\
\text { studies } \\
\text { - Mentoring during training } \\
\text { courses and teaching in schools } \\
\text { - Research and development } \\
\text { projects, Bachelor and Master } \\
\text { thesis } \\
\text { - } \ldots\end{array}$ \\
\hline 5 & $\begin{array}{l}\text { Research on practice } \\
\text { Action research }\end{array}$ & $\begin{array}{l}\text { - Conducting research with the } \\
\text { aim of improving teaching } \\
\text { practice and enhancing } \\
\text { teaching quality }\end{array}$ & $\begin{array}{l}\text { - Observations } \\
\text { - Portfolios, diary, video aids } \\
\text { reflection related to teaching } \\
\text { activities } \\
\text { - Project, Bachelor and Master } \\
\text { thesis } \\
\text { - ... }\end{array}$ \\
\hline 6 & $\begin{array}{l}\text { Research activities with } \\
\text { the target audience } \\
\text { "scientific community" }\end{array}$ & $\begin{array}{l}\text { - Research based on } \\
\text { state-of-the-art depending on } \\
\text { different disciplines }\end{array}$ & $\begin{array}{l}\text { - Bachelor and Master thesis; } \\
\text { dissertation } \\
\text { - Scientific work, publications } \\
-\ldots\end{array}$ \\
\hline
\end{tabular}

Adapted from Altrichter and Mayr (2004) and Bieri Buschor et al. (2013)

dents gain knowledge to simulate a research process (e.g., conducting experiments in natural sciences). (3) In the third type, students assume a more active role as researchers. While participating in a research project guided by an experienced researcher, they begin to learn the process of conducting research. (4) The fourth type refers to learning by means of case studies with a strong focus on deep comprehension. The aim is to gain knowledge by comparing cases (e.g., understanding patterns of teacher-student interaction, schools, etc.). Typical learning settings are workshops designed to collaboratively analyze cases or mentoring sessions during training courses and teaching in schools. (5) The fifth type encompasses action research in terms of cycles of inquiry in the classroom. In contrast to traditional educational research, the goal is to enable teachers to develop their knowledge and skills by engaging in 
research that will aid them directly in every day teaching situations rather than in creating theories or concepts. Nevertheless, action research also contributes important knowledge to the pedagogical field (Henning et al. 2009; Altrichter et al. 2004). (6) The sixth type of research represents research activities within the scientific community, which is rather rare in teacher education.

The two schemes presented above provide a valuable framework within which to analyze the curriculum in teacher education. They range from gaining scientific literacy by means of instruction and knowledge transmission (see types 1 and 2 in Table 1), to acquiring knowledge while participating in research projects or conducting one's own research project (see types 3-5 in Table 1). Types 3-5 of Altrichter and Mayr's categorization of research additionally aim to support (co-)reflection (2004).

\subsection{Curriculum analysis: learning settings fostering student teachers' reflective attitude and research-oriented stance}

The aim of this article is to discuss how student teachers can be supported in developing a reflective attitude and research-oriented stance. For this purpose, we analyzed different learning settings from the curriculum of the Zurich University of Teacher Education. In accordance with Helsper and Kolbe (2002) and So (2013), we define the term researchoriented stance as investigative habitus, including reflective activities (Kamm and Bieri 2008): the students (1) develop an attitude towards practice as an "observable topic" (by means of gaining distance from a phenomenon) and maintain a curiosity toward teaching, (2) acquire basic knowledge related to collecting and analyzing data by using research methods, and (3) (co-) reflect on their teaching experiences and their learning process.

Curriculum analysis approaches range from more inductive approaches, using, for example, strategies from document analysis or case studies, to more criteria-based approaches (Pinar et al. 1995; Westbury et al. 2005). For our purpose, we primarily use Altrichter and Mayr's (2004) categorization of research in terms of criteria to select appropriate learning settings. In accordance with Healey and Jenkins' (2009) scheme, we additionally account for the two criteria (1) guided versus more self-regulated learning settings, and (2) traditional versus recent approach to enhance student teachers' research activities.

The analysis is based in the context of the formal curriculum at the Zurich University of Teacher Education, one of the largest Swiss universities of teacher education, which provides initial teacher education for future teachers at all school levels (except for upper secondary school level with the highest requirements), continuing professional development courses, research, and services. It was established at a tertiary level in 2001. Training programmes differ according to the different levels of teaching. Kindergarten and primary school student teachers (grades 0-6) study five-seven subjects in pursuit of a Bachelor's degree. Secondary school student teachers study four-five subjects and require a Master's degree that enables them to teach at the lower secondary level (grades 7-9). The amount of subjects Swiss teachers teach is higher-compared to other European countries. Students of all levels are given the opportunity to study full- or part-time. Special needs education is incorporated into their studies. Kindergarten and primary school student teachers attend courses with a value of 2 ECTS credit points (European credit transfer system, equivalent of 60 working hours). The curriculum for secondary school students encompasses 4 ECTS (120 working hours). Research and extended practical teaching experience, which are strongly alternated, have been core elements of the curriculum ever since. Student teachers of all levels are enrolled in teaching activities in co-operating schools 1 day a week from the outset. Firstly, student teachers are engaged in a teaching practicum (I) of 3 weeks in a co-operation school after 
their first year of studies. Secondly, they do an extended practicum (II) in another school in the fourth semester (primary school level), respectively, sixth semester (secondary school level), comprising the following phases: (1) first planning phase of 4 weeks, (2) first part of teacher practicum lasting 3 weeks, 3 ) reflection and second planning phase (1 week), (4) second part of the teacher practicum lasting 3 weeks, and (5) extended reflection phase (1 week). Thirdly, student teachers assume full responsibility as classroom teachers for 3 weeks 6 months before completing their studies (practicum III). Concurrently, the regular teachers of these classes attend continuous education studies courses at the university. Finally, student teachers demonstrate their competencies in a subsequent 2-week practicum (practicum IV), which is part of the final assessment.

Three learning settings will be described in this section. The first represents a more traditional approach to supporting secondary school student teachers' reflective activity and research-oriented stance through action research during the last two (of eight-nine) semesters, while writing their Master's thesis. The second refers to a participatory research project for all student teachers' in their third or fourth semester. Finally, the third approach represents one that combines video-based competence training and reflection by using video analysis from part of the second, extended practicum (practicum II see above) comprising exposing student teachers to different phases of planning, teaching, and reflection.

\subsubsection{Action research project "Master thesis"}

This is the first learning setting, i.e., an action research project conducted by student teachers for secondary schools in the master's programme during their last two to three semesters (out of the total eight-nine). It is important to note that a considerable amount of students extend their master's studies to nine semesters rather than to complete their studies within eight semesters because they are concurrently working part-time in schools due to current teacher shortage. The master's programme includes not only practicum III and IV and a few subjectrelated courses, but also the Master's thesis with a workload of 25 ECTS. Students who have access to classrooms either because they teach or have access for a longer period of time (a minimum of 12 weeks) are given the opportunity to write their Master's thesis based on an action research project. During this phase, students are supported by one-two supervisors (depending on the topic), and attend courses and meetings to help them to co-reflect on their experience. The aim of the project which lasts 40 weeks, including four-seven preparatory courses of 2-4h, is to build up student teachers' research-oriented stance and to help them in their professional development. The courses strengthen student teachers' competencies in the field of academic writing, selection of appropriate literature, project management skills, planning of phases of action, and reflective cycles, as well as their ability to apply adequate research methods. For the Master's thesis, students plan and conduct at least two cycles of inquiry. One cycle comprises action in the classroom (e.g., changes in the classroom management), the collection and analysis of data (e.g., video analysis, students' feedback) related to the observation of the effectiveness of the action, as well as the derivation of the subsequent cycle under the guidance of a supervisor. In addition, students build collaborative inquiry groups in order to establish a peer-coaching system (Cochran-Smith and Lytle 2009). For this purpose, specific instruments for co-reflection and peer-coaching sessions, in groups of approximately five-eight students who meet on a regular basis (every month or every second month according to the phase of their Master's thesis project), are provided. Whereas some of the meetings are guided by experienced researchers, some are organized by the students themselves. The focus is on the following "critical" phases during the project: (1) finding an appropriate research question, (2) planning the action research project (project 
management), (3) involving students and colleagues in the workplace, (4) collecting and analyzing data, and (5) drawing conclusions for the next cycle of inquiry.

\subsubsection{Participatory research project: learning in the field of special needs education}

The second learning setting is a participatory research project based on a course in the field of special needs education, lasting half a day (4 lessons) for a period of 12 weeks, in the third or fourth semester. The module aims to enhance students' diagnostic competencies and knowledge acquisition in relation to pupil observation, assessment, and specific planning based on a framework of indicators for inclusive education to support students individually (Luder 2011; Hollenweger et al. 2011). The focus is on students' co-reflection on the correlations between teaching, assessment, feedback, and students' self-concept. Additionally, students learn how to use instruments, such as the indicators for inclusive education, in different case studies. Didactically, the module is based on principles from problem-based learning, with students working on authentic cases, in teams. The case studies stem from a research project designed to investigate experienced teachers' planning and activities in special needs education. Artifacts and documents on students with special needs, such as test results, assessments, essays, teachers' and other professionals' reports, video sequences related to classroom situations, and meetings with parents were adapted for this learning setting and provided on an online platform. The students actively participate in the research project by writing their analysis and reflections on experienced teachers' activities and program planning for children with special needs in online diaries, as well as providing feedback to teachers' activities. However, this feedback is primarily provided to researchers and other students in the course. Teachers also have access to students' feedback. Student teachers write assignments on the cases observed, and take care to include their own and colleagues' feedback, while concurrently trying to establish a link to theoretical aspects. The researchers, in turn, observe student teachers' diagnostic competencies and knowledge acquisition from one case study to the other. Therefore, student teachers play a dual role. Firstly, they actively participate in the research project by analyzing experienced teachers' activities in the classroom. Secondly, they are in turn observed by researchers who assess their competence development while on the course.

\subsubsection{Reflection and competence training by means of video analysis: the module "teaching quality"}

The third learning setting, the module "teaching quality," is a combination of researchoriented activities, video-based reflection, and training of teaching competencies. It occurs within the second practicum (see above practicum II) and lasts for $4 \mathrm{~h}$ over a period of 12 weeks. The rationale behind the learning setting is informed by a large longitudinal study of teachers' competencies conducted by Baer et al. (2011). In this study, which is based on the expert-novice paradigm and constructivist approaches to teaching, pre-service and beginning teachers' lessons are compared to expert teachers' teaching quality. The results indicate the major importance of cognitive activation. During the preparation phase, students reactivate their prior knowledge of teaching quality and broaden their knowledge by analyzing videotaped lessons from empirical studies, including ethical issues. In the first 4 weeks of practicum II, student teachers record two of their own lessons: the first is a teacher-centered lesson, while the second is a student-centered lesson. Back at university, they analyze their videos in groups of three, meaning that there are six videos per group. They undertake 
a rating of every observed lesson in accordance with a list of criteria for good teaching practice. The discussion rules state that the students seen in the respective video are not allowed to comment or explain what they intended to do. Instead, the students listen to peer feedback. The aim of this procedure is to support students' reflective teaching and enhance their awareness of strengths and weaknesses of their own teaching practice. Then, student teachers choose one "research question" which they wish to investigate, or focus on an area that they want to improve. In a subsequent period of investigation, students endeavor to improve their 'shortcomings' by studying the empirical results of their study which form the basis for lesson planning for the second part of the practical teaching experience. This second part is a coaching phase guided by experienced lecturers who help student teachers to hunt for the relevant literature required. In the subsequent practical phase, students record the lesson they had planned during the coaching phase. Finally, students draw conclusions about their learning process and write a report about their individual questions related to teaching, using relevant theories learnt and reflecting upon their practical teaching experience.

Overall, these three approaches represent different categories of research according to Altrichter and Mayr (2004) (see Table 1). Whereas approach A clearly represents type 5, referring to action research with a focus on teaching improvement, B and C cannot so simply be assigned to one single type. Learning setting B primarily refers to type 3 , while partly matching with type 4. It represents a more guided learning setting based on case studies (problem-solving scenarios) with a focus on deep comprehension. Even though students do participate in a research project, they do not play a very active role in it. In contrast, approach $\mathrm{C}$ involves student teachers in the research process and, therefore, partly represents type 3 with a great amount of overlapping with type 4 as student teachers gain knowledge by means of comparison with peers and expert teachers. In addition, this can also be seen as research in practice (type 5).

\section{Conclusion}

The aim of this article was to discuss how student teachers can be supported in developing a reflective attitude and research-oriented stance. Referring to schemes to analyze research in teacher education (Healey and Jenkins 2009), we state that the three learning settings described above are located in the quadrant "research-based learning" (Fig. 1) because they strongly support students' active role in the learning process. However, in learning setting $\mathrm{B}$, student teachers are not strongly involved as researchers. Whereas learning setting A focuses on the student teachers' role as researchers with a high amount of autonomy, setting $\mathrm{C}$ stresses the importance of reflective teaching in combining phases of co-reflection and (peer-) coaching with competence-based training. Using Altrichter and Mayr's (2004) categorization (Table 1), they represent types 3-5, emphasizing research with a strong link to teaching practice and quality. They appear to be suitable for supporting student teachers' investigative habitus (research-oriented stance) because they involve student teachers in conducting research, including reflection-on-action. However, all settings also incorporate elements of scientific literacy (types 1 and 2).

Furthermore, Table 2 shows that the learning settings (types A-C) differ in their level of approximations of practice, nature of reflection, and levels of requirement related to theories.

Whereas types $\mathrm{A}$ and $\mathrm{C}$ are based on (approximations of) practice, and therefore, have a strong theory-practice nexus, learning setting $\mathrm{B}$ has only an indirect link to practice by means of cases. (Co-)reflection is used as a didactical "carrier" in all learning settings in order to build a bridge between theory and practice, albeit different in nature. In type B, 
Table 2 Learning settings (types) and their different approximations of practice, natures of reflection, and levels of requirement related to theories

\begin{tabular}{|c|c|c|c|}
\hline & $\begin{array}{l}\text { Action research } \\
\text { (type A) }\end{array}$ & $\begin{array}{l}\text { Participatory } \\
\text { research (type B) }\end{array}$ & $\begin{array}{l}\text { Video-based reflection } \\
\text { and competence } \\
\text { training (type C) }\end{array}$ \\
\hline $\begin{array}{l}\text { Action: } \\
\text { approximations of } \\
\text { practice }\end{array}$ & $\begin{array}{l}\text { - Real, contemporary } \\
\text { teaching practice } \\
\text { - Acting under } \\
\text { uncertainty }\end{array}$ & $\begin{array}{l}\text { - Simulations of practice: } \\
\text { indirect impact on } \\
\text { teaching due to deep } \\
\text { comprehension }\end{array}$ & $\begin{array}{l}\text { - Approximations of } \\
\text { practice }\end{array}$ \\
\hline $\begin{array}{l}\text { Reflection to build a } \\
\text { bridge between } \\
\text { theory and practice } \\
\text { (didactical } \\
\text { approach) }\end{array}$ & $\begin{array}{l}\text { - Reflection-on-action } \\
\text { - Co-reflection }\end{array}$ & $\begin{array}{l}\text { - Co-reflection on cases } \\
\text { based on theories } \\
\text { ("clinical approach") }\end{array}$ & $\begin{array}{l}\text { - "Mirroring": creating a } \\
\text { distance by (a) an } \\
\text { "objective self", (b) } \\
\text { comparison with } \\
\text { standards in teaching } \\
\text { (e.g., expert teachers) }\end{array}$ \\
\hline \multirow[t]{2}{*}{$\begin{array}{l}\text { Theory (research): } \\
\text { levels of } \\
\text { requirement }\end{array}$} & $\begin{array}{l}\text { - Scrutinizing (student) } \\
\text { teachers' beliefs } \\
\text { (subjective theories) }\end{array}$ & $\begin{array}{l}\text { - Theoretical knowledge } \\
\text { and case-based } \\
\text { knowledge }\end{array}$ & - Theoretical models \\
\hline & $\begin{array}{l}\text { - Theoretical and } \\
\text { case-based knowledge } \\
\text { - Practical knowledge }\end{array}$ & - General knowledge & $\begin{array}{l}\text { - Empirical studies on } \\
\text { quality teaching, } \\
\text { competence-based } \\
\text { teaching and standards }\end{array}$ \\
\hline
\end{tabular}

it is used to share ideas and knowledge rather than the students' own teaching experience because the setting is not contemporary. In type $\mathrm{C}$, it is extended to the concept of "mirroring": not only do student teachers gain distance from their own teaching and their own self through the use of videos, but they also compare their teaching with set standards in teaching quality. In all of these settings, theory and research are strongly linked to action. Yet, theory is related to different levels of requirement. Action research (type A), for instance, aims to scrutinize student teachers' beliefs in teaching and to broaden theoretical and practical knowledge. Participatory research (type B), in contrast, refers to general theoretical and case-based knowledge. The video-based competence training represents the current didactical approach to improving teaching quality. In this setting, reflection can also be perceived as a didactical tool to achieving normative standards in teaching, represented by experts' teaching. This is in contrast to the original concept of Dewey's (1933) and Schön's (1983) emancipatory approach to personal growth. Nevertheless, the combination of reflection, research-oriented activities, and competence training is timely. In recent years, the call for a more competencebased curriculum has strongly influenced teacher education (Kraler and Schratz 2012). One example of this is the call for inquiry-based science teaching competencies (Alake-Tuenter 2013). The learning settings seem to be suitable for different phases of teacher education. Type A, in particular, seems to be suitable for a masters' programme because it does not only contribute to teaching quality (Hagevik et al. 2012), but it also strengthens student teachers' autonomy and professional development during the phase of transition to teaching ( Borko et al. 2010). In contrast, type B can be incorporated into earlier phases of teacher training because it strengthens students' knowledge acquisition and competence development. Even though student teachers are involved in research-based learning (Healey and Jenkins 2009), their research activities seem to be strongly regulated by the researchers rather than regulated by the students. Finally, type $\mathrm{C}$, which is linked to research in practice and competence development in the classroom, seems to be a challenging combination that can only be placed in a 
practicum posting in a later phase of teacher training as students need to adapt their roles in a highly flexible way. Conducting research, including reflection-in and on-action (Schön 1983), while concurrently improving teaching competencies in the classroom through comparison, feedback, and co-reflection, demands a great deal out of students teachers. It, therefore, requires an adequate support structure as was suggested by Gelfuso and Dennis (2014).

The learning settings discussed in this article meet the following requirements: they provide opportunities for learning in terms of knowing why and knowing that. They foster student teachers' reflective attitude and research-oriented stance. Yet, it is clear that lecturers and researchers play a very active role in the process of conducting research and co-reflection. The learning settings are carefully designed to establish a balance between the students' need to know how and activities focusing on gaining knowledge on knowing that. Moreover, lecturers and researchers provide a great/significant amount of (peer-) coaching sequences and scaffolding elements by introducing instruments to facilitate, for instance, co- reflection. Supervising this type of research and reflection requires a broad knowledge base, not only in research and teaching but also in coaching. More research is needed to evaluate how different types of didactical approaches concurrently enhance (student) teachers' reflective attitudes, research-oriented stances, and competencies in teaching.

\section{References}

Abell, S. K., \& Cennamo, K. S. (2004). Videocases in elementary science teacher preparation. In J. Brophy (Ed.), Using video in teacher education (pp. 103-130). Oxford: Elsevier.

Alake-Tuenter, E. (2013). Inquiry-based science teaching competence of primary school teachers: A Delphi study. Teaching and Teacher Education, 35, 13-24.

Allan, R. (2000). Knowing how and knowing that. A Polanyi view. In G. H. Neuweg (Ed.), Wissen, Können, reflexion [knowledge, competence, reflection] (pp. 45-63). Innsbruck: Studienverlag.

Altrichter, H., \& Mayr, J. (2004). Forschung in der Lehrerbildung [Research in teacher education]. In S. Blömeke, P. Reinhold, G. Tulodziecki, \& J. Wildt (Eds.), Handbuch Lehrerbildung [Handbook on teacher education] (pp. 164-183). Bad Heilbrunn: Klinkhardt.

Altrichter, H., \& Posch, P. (2007). Lehrerinnen und Lehrer erforschen ihren Unterricht [Teachers investigate their teaching]. Bad Heilbrunn: Klinkhardt.

Altrichter, H., Posch, P., \& Somekh, B. (2004). Teachers investigate their work. An introduction to the methods of action research. New York: Routledge.

Antoniou, P., \& Kyriakides, L. (2013). A dynamic integrated approach to teacher professional development: Impact and sustainability of the effects on improving teacher behaviour and student outcomes. Teaching and Teacher Education, 29, 1-12.

Baecher, L., Kung, S. C., Jewkes, A., \& Rosalia, C. (2013). The role of video for self-evaluation in early field experiences. Teaching and Teacher Education, 36, 189-197.

Baer, M., Guldimann, T., Kocher, M., \& Wyss, C. (2011). Wissenschaftlicher Schlussbericht zuhanden des Schweizerischen Nationalfonds zum Forschungsprojekt "Standarderreichung beim Erwerb von Unterrichtskompetenz im Lehrerstudium und im Übergang zur Berufstätigkeit “ [Scientific report of the project "Achieving standards during the acquisition of teaching competencies in teacher training and during the phase of transition to the teaching profession" for the Swiss National Science Foundation] (SNF 100014-124956). Zürich: Pädagogische Hochschule.

Ball, S. J. (2008). The education debate. Bristol: The Policy Press.

Ball, D., \& Forzani, F. (2009). The work of teaching and the challenge for teacher education. Journal of Teacher Education, 60, 497-510.

Bieri Buschor, C., Luder, R., \& Kamm, E. (2013). Elfenbeinturm ade! Forschungsorientiertes Lernen und Lehren an pädagogischen Hochschulen [Good-bye ivory tower! Research-oriented learning and teaching at universities of teacher education]. In H. Bachmann (Ed.), Hochschullehre variantenreich gestalten [Variations of learning settings in higher education] (pp. 78-103). Bern: h.e.p.

Borko, H., Jacobs, J., \& Koellner, K. (2010). Contemporary approaches to teacher professional development: Processes and content. In P. Peterson, E. Baker \& B. McGaw (Eds.), International encyclopedia of education (Vol. 7, pp. 548-556). 
Clark, P. A. J., \& Fournillier, J. B. (2012). Action research, pedagogy, and activity theory: Tools facilitating two instructors' interpretations of the professional development of four preservice teachers. Teaching and Teacher Education, 28, 649-660.

Cochran-Smith, M., \& Lytle, S. L. (1993). Inside/outside: Teacher research and knowledge. New York: Teachers' College Press.

Cochran-Smith, M., \& Lytle, S. L. (1999). Relationships of knowledge and practice: Teacher learning in communities. Review of Research in Education, 24, 249-305.

Cochran-Smith, M., \& Lytle, S. L. (2009). Inquiry as stance: Practitioner research for the next generation. New York: Teachers College Press.

Combe, A., \& Gebhard, U. (2012). Verstehen im Unterricht. Zur Rolle von Phantasie und Erfahrung [Comprehension in teaching. On the role of imagination and experience]. Wiesbaden: Verlag für Sozialwissenschaften.

Criblez, L. (2008). Die Reform der Lehrerinnen- und Lehrerbildung in der Schweiz seit 1990 [Reforms of Swiss teacher education since 1990]. In H. Ambühl \& W. Stadelmann (Eds.), Tertiarisierung der Lehrerinnenund Lehrerbildung [Tertiarization of teacher education] (pp. 22-58). Bern: EDK.

Darling-Hammond, L. (2010). The flat world and education. How America's commitment to equity will determine our future. New York: Teachers College Press.

Darling-Hammond, L., \& Sclan, E. M. (2002). Dilemmas of building a profession for twenty-first century schools. In V. Richardson (Ed.), Handbook of research on teaching (4th ed., pp. 76-101). Washington, DC: American Educational Research Association.

Denzler, S. (2014). Integration of teacher education into the Swiss higher education system. Dissertation, University of Lausanne. http://my.unil.ch/serval/document/BIB_98AF6E7FC8D6.pdf.

Denzler, S., \& Wolter, S. C. (2009). Sorting into teacher education: How the institutional setting matters. Cambridge Journal of Education, 39(4), 423-441.

Dewey, J. (1904). The relation of theory to practice in education. In C. A. McMurry (Ed.), The relation of theory to practice in the education of teachers. Bloomington, IL: Public School Publishing.

Dewey, J. (1933). How we think. New York: Heath and Co.

Ermeling, B. A. (2010). Tracing the effects of teacher inquiry on classroom practice. Teaching and Teacher Education, 26, 377-388.

Gelfuso, A., \& Dennis, D. V. (2014). Getting reflection off the page: The challenges of developing support structures for pre-service teacher reflection. Teaching and Teacher Education, 38, 1-11.

Gitlin, A., Barlow, L., Burbank, M. D., Kauchak, D., \& Stevens, T. (1999). Pre-service teachers' thinking on research: Implications for inquiry oriented teacher education. Teaching and Teacher Education, 15, $753-769$.

Griffiths, R. (2004). Knowledge production and the research-teaching nexus: The case of the built environment disciplines. Studies in Higher Education, 29(6), 709-726.

Grossman, P. (2011). A framework for teaching practice: A brief history of an idea. Teachers College Record, 113(12). http://tc.record.org.

Grossman, P., \& McDonald, M. (2008). Education back to the future: Directions for research in teaching and teacher education. American Educational Research Journal, 45(1), 148-205.

Guskey, T. R. (2000). Evaluating professional development. Thousand Oaks, CA: Corwin Press.

Hagevik, R., Aydeniz, M., \& Rowell, C. G. (2012). Using action research in the middle level teacher education to evaluate and deepen reflective practice. Teaching and Teacher Education, 28, 675-684.

Healey, M. (2005). Linking research and teaching: Exploring disciplinary spaces and the role of inquiry-based learning. In R. Barnett (Ed.), Reshaping the university. New relationships between research, scholarship and teaching (pp. 76-78). Maidenhead: McGraw/Open University Press.

Healey, M., \& Jenkins, A. (2009). Developing undergraduate research and inquiry. New York: The Higher Education Academy.

Helsper, W., \& Kolbe, F. U. (2002). Bachelor/Master in der Lehrerbildung - Potential für Innovation oder ihre Verhinderung? [Bachelor/Master in teacher education-Potential for innovation or hindrance?]. Zeitschrift für Erziehungswissenschaft, 5(3), 384-400.

Helsing, D. (2007). Regarding uncertainty in teachers and teaching. Teaching and Teacher Education, 23, 1317-1333.

Henning, J. E., Stone, J. M., \& Kelly, L. J. (2009). Using action research to improve instruction. An interactive guide for teachers. London: Routledge.

Hollenweger, J., Rouse, M., Kyriazopoulou, M., \& Weber, H. (2011). Participation in inclusive education. A. Framework for developing indicators. Brussels: European Agency for Development in Special Needs Education.

Kleinknecht, M., \& Schneider, J. (2013). What do teachers think and feel when analysing videos of themselves and other teachers teaching? Teaching and Teacher Education, 33, 13-23. 
Korthagen, F. A. J., Kessels, J., Koster, B., Lagerwerf, B., \& Wubbels, T. (2001). Linking practice and theory: The pedagogy of realistic teacher education. Mahwah, NJ: Lawrence Erlbaum.

Kraler, C., \& Schratz, M. (2012). From best practice to next practice: A shift through research-based teacher education. Reflecting Education, 8(2), 88-125.

Kynäslahti, H., Kansanen, P., Jyrhämä, R., Korkfors, L., Maaranen, K., \& Toom, A. (2006). The multimode programme as a variation of research-based teacher education. Teaching and Teacher Education, 22, $246-256$.

Kyvik, S. (2009). The dynamics of change in higher education. Expansion and contraction in an organisational field. Dordrecht: Springer.

Luder, R. (2011). örderplanung als interdisziplinäre und kooperative Aufgabe [Planning in special needs education as an interdisciplinary and cooperative task]. In R. Luder, R. Gschwend, A. Kunz, \& P. Diezi-Duplain (Eds.), Sonderpädagogische Förderung gemeinsam planen. Grundlagen, Modelle und Instrumente für eine interdisziplinäre Praxis [Co-planning in special needs education. Basics, models and instruments for an interdisciplinary practice] (pp. 11-18). Zürich: Pestalozzianum.

Masats, D., \& Dooly, M. (2011). Rethinking the use of video in teacher education: A holistic approach. Teaching and Teacher Education, 27, 1151-1162.

OECD. (2005). Teachers matter. Attracting, developing and retaining effective teachers. Paris: OECD Publishing.

Oevermann, U. (1996). Theoretische Skizze einer revidierten Theorie professionalisierten Handelns [Theoretical outline of a revised theory of professional action]. In A. Combe \& W. Helsper (Eds.), Pädagogische Professionalität [Educational professionalism] (pp. 70-182). Frankfurt am Main: Suhrkamp.

Ostermann, K. F., \& Kottcamp, R. B. (2004). Reflective practice for educators: Professional development to improve student learning. Thousand Oaks, CA: Corwin Press.

Ottesen, E. (2007). Reflection in teacher education. Reflective Practice, 8(1), 31-46.

Pinar, W. F., Reynolds, W. M., Slattery, P., \& Taubman, P. M. (1995). Understanding curriculum. New York: Peter Lang Publishing.

Polanyi, M. (1958). Personal knowledge. Chicago: The University of Chicago Press.

Rigelman, N., \& Ruben, B. (2012). Creating foundations for collaboration in schools: Utilizing professional learning communities to support teacher candidate learning and visions of teaching. Teaching and Teacher Education, 28, 979-989.

Ryle, G. (1949). The concept of mind. London: Hutchinson.

Santagata, R., \& Guarino, J. (2011). Using video to teach future teachers to learn from teaching. Mathematics Education, 43, 133-145.

Schnellert, L., Butler, D. L., \& Higginson, S. (2008). Co-construction of data, constructors of meaning: Teacher professional development in an age of accountability. Teaching and Teacher Education, 24(3), 725-750.

Schön, D. A. (1983). The reflective practitioner: How professionals think in action. New York: Basic Books.

Schön, D. A. (1987). Educating the reflective practitioner. Toward a new design for teaching and learning in the professions. San Francisco: Jossey Bass.

Seidel, T., Blomberg, G., \& Renkl, A. (2013). Instructional strategies for using video in teacher education. Teaching and Teacher Education, 34, 56-65.

Shulman, L. S. (1987). Knowledge and teaching: Foundations of the new reform. Harvard Educational Review, 57(1), 1-22.

Shulman, L. S., \& Shulman, J. (2004). How and what teachers learn: A shifting perspective. Curriculum Studies, 36(2), 257-271.

So, K. (2013). Knowledge construction among teachers within a community based on inquiry as stance. Teaching and Teacher Education, 29, 188-196.

Van Manen, M. (1977). Ways of knowing with ways of being practical. Curriculum Inquiry, 6(3), 205-228.

Van Manen, M. (1995). On the epistemology of reflective practice. Teachers and Teaching: Theory and Practice, 1(1), 33-50.

Westbury, I., Hansen, S. E., Kansanen, P., \& Björkvist, O. (2005). Teacher education of research-based practice in expanded roles: Finland's experience. Scandinavian Journal of Education Research, 49(5), 475-485.

Wyss, C. (2013). Job entry phase in the teaching profession. Theoretical and empirical considerations with special regard to the concept of reflection. In J. Seifried \& E. Wuttke (Eds.), Transitions in vocational education, research in vocational education (Vol. 2, pp. 239-258). Farmington Hills, MI: Budrich Publisher.

Zeichner, K. (1993). Traditions of practice in U.S. teacher education programs. Teaching and Teacher Education, 9(1), 1-13.

Zeichner, K. (2010). University-based teacher education. Rethinking the connections between campus courses and field experiences in college- and university-based teacher education. Journal of Teacher Education, 89(11), 89-99. 
Zeichner, K. (2012). The turn once again toward practice-based teacher education. Journal of Teacher Education, 63(5), 376-382.

Zeichner, K. M., \& Liston, D. P. (1987). Teaching student teachers to reflect. Harvard Educational Review, $57(1), 23-49$.

Zeichner, K. M., \& Liston, D. P. (1996). Reflective teaching. An introduction. Mahwah, NJ: Lawrence Erlbaum Associates. 